\title{
METHODYC'S OF FORMATION OF ARTISTIC AND IMAGINAL THINKING OF STUDENTS-VOCALISTS
}

The article forms and fully reveals the four stages of formation of artistic and figurative thinking of students - vocalists and singing teachers. The vocal training system has strong, time-tested traditions, but needs to be improved in line with today's new requirements. The study of the peculiarities of the influence of the educational process on the formation of artistic and figurative thinking of students-vocalists is an urgent scientific problem. The success of the educational process of student vocalists largely depends on the level of formation of systemic musical-historical and theoretical-methodical knowledge and ways of their transfer in relation to the spiritual context of artistic culture of the past and present. Modern higher education should provide training for an active, independent, creative specialist, able to constantly search for non-standard ways to solve any production problem, use the achievements of scientific and technological progress, implementation and self-realization of their essential strengths in various activities. This approach will overcome the contradictions between the social order of society for music education of vocally gifted youth and insufficiently qualified pedagogical support of the educational process in the system of higher music institutions of Ukraine, which train professional singers and teachers.

The proposed method has its special advantages over the existing ones, because the starting point is a set of natural data and the ability to teach the student to sing, and not just the methodological techniques of the teacher. The gradual mastering of professional skills and abilities of independent work at students, ability to self-analysis and critical selfestimation, high mobility in unforeseen situations is analyzed. This methodological perspective of understanding the process of forming artistic and figurative thinking of vocal students is very timely, given the strengthening of the scientific potential of singers and vocal teachers in modern Ukraine.

Key words: artistic and figurative thinking, creative process, information and cognitive aspect, pedagogical methods, creativity, creative education, tutoring.

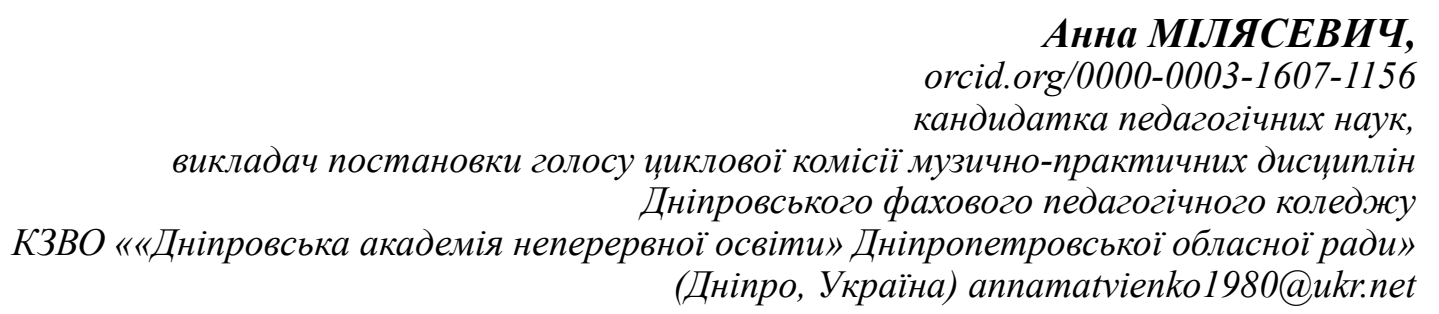

\section{ПОЕТАПНА МЕТОДИКА ФОРМУВАННЯ ХУДОЖНЬО-ОБРАЗНОГО МИСЛЕННЯ СТУДЕНТІВ-ВОКАЛІСТІВ}

У статті сформовані і повною мірою розкриті чотири етапи формування художньо-образного мислення студентів - вокалістів і викладачів співу. Система навчання вокалу має міџні, перевірені часом традицї, але потребує вдосконалення відповідно до нових сучасних вимог. Вивчення особливостей впливу навчально-виховного проиесу на формування художньо-образного мислення студентів-вокалістів є актуальною науковою проблемою. Успіх навчально-виховного прочесу студентів-вокалістів значною мірою залежить від рівня сформованості в них системних музично-історичних та теоретико-методичних знань і способів їх передачі у співвіднесенні з духовним контекстом художньої культури минулого та сьогодення. Сучасна вища освіта має забезпечити підготовку активного, самостійного, творчого фахівия, здатного до постійного пошуку нестандартних способів вирішення будь-якого виробничого завдання, використання досягнень науково-технічного прогресу, реалізачї та самореалізачії своїх сутнісних сил у різних видах діяльності. Такий підхід дозволить подолати суперечності й між соціальним замовленням суспільства на музичну освіту вокально обдарованої молоді та недостатньо кваліфікованим педагогічним забезпеченням навчально-виховного процесу в системі вищих музичних закладів Украӥни, які готують професійних співаків і викладачів. 
Запропонована методика має свої особливі переваги над тими, щуо наявні та відомі, адже вихідним моментом $\epsilon$ комплекс природних даних та здатність до навчання співу учня, а не одні лише методичні прийоми вчителя. Аналізується поступове опанування професійної майстерності та навичок самостійної роботи студентів. Даний методологічний ракурс осмислення процесу формування художньо-образного мислення студентіввокалістів є дуже своєчасним, зважаючи на посилення в сучасній Україні наукового потенціалу співаків та педагогів-вокалістів.

Ключові слова: художньо-образне мислення, творчий процес, інформаційно-когнітивний аспект, педагогічні методи, креативність, креативне виховання, тьюторський супровід.

Formulation of the problem. The process of formation of artistic and figurative thinking of student vocalists must be carried out consciously and purposefully. To implement it, the following task must be solved: 1) to form an effective level of development of students-vocalists of artistic and figurative thinking; 2) to organize classes with methods of creative use of traditional and non-traditional methods of formation of artistic and figurative thinking; 3 ) to develop plans for lectures and practical classes, taking into account the pedagogical principles of the process of forming artistic and figurative thinking of future singers in the process of mastering new tasks. This process should be carried out in individual, group and extracurricular activities with further creative development of the teacher-defined areas of spiritual development and musical intelligence of the individual. In the process of identifying these areas should be used provisions related to the identification and performance of the musical image of the work: a) the formation of the performance repertoire; $b$ ) identification of its methodological aspect; c) its inclusion in the general cultural context through the formation of ideas about the era, style, genre of the work; d) the choice of analogies from other arts, which contribute to the expansion of the artistic worldview of the student. It was found that these provisions are insufficiently implemented in vocal pedagogy and performance. Pedagogical and semantic-methodological aspects of the formation of artistic and figurative thinking of singing teachers remain insufficiently researched and modernized.

Analysis of recent research and publications. The lack of modern scientific literature on the work of students-vocalists is due to insufficient education and training of young teachers-vocalists. It should be noted that the works on which the author relies embrace the end of the XX - beginning of the XXI century (meaning works: V. Antonyuk (Антонюк, 1995; Антонюк, 1999; Антонюк, 2000; Антонюк, 2007; Антонюк, 2009), D. Bogoyavlenskaya (Богоявленская, 2002), V. Yemelyanov (Емельянов, 1991; Емельянов, 2000), I. Kolodub (Колодуб, 1995), O. Oleksyuk (Олексюк, 2004a; Олексюк, 2004b; Олексюк, 2006), G. Padalka (Падалка, 1991; Падалка, 1995). The analysis of this series of studies led to the conclusion that there is a lack of published works writ- ten by practicing teachers-vocalists, which would be directly related to the staging of the voice and its specifics in the synthesis with the psychological features of this process. Therefore, at present it is relevant to study the process of formation of artistic and figurative thinking of students-vocalists in classes on voice production.

Turning to the methods of vocal-pedagogical action, we are faced, first of all, with empirical guidelines: "do as I do", "listen to yourself". However, the complexity of musical-performing actions in the vocal art requires consistent mastering of all components of the performing and pedagogical process on the basis of rather significant objective criteria, i.e. in the form of regularities. The specifics of vocal training in the context of music education in the organization of the inseparable unity of the following processes: 1) knowledge transfer; 2) transfer of vocal abilities; 3) the formation of personal significance of musical values. In the broad sense of the process of formation of artistic and figurative thinking of vocalists should be understood as a systematic interaction of vocal-musical component with aesthetic, creative and pedagogical components that complement, interact, mediate each other.

The success of the educational process of student vocalists largely depends on the level of formation of systemic musical-historical and theoretical-methodical knowledge and ways of their transfer in relation to the spiritual context of artistic culture of the past and present. The function of a teacher of historical and theoretical disciplines in the system of educational process of vocalists is interpreted as a way to include musical language in a broad cultural and artistic context. Artistic and figurative training of vocal students involves the ability to see a certain system of musical language for each unique text of a vocal work, which embodies the general semantic and communicative means of musical expression, as well as the ability to correlate individual identity and figurative thinking.

This is taught in individual and group classes. This is primarily a consistent form of integrative communication, which prioritizes the development of applied aspects of individual vocal learning, directly related to the personal development of artistic thinking, as well as - a synthetic form of communication designed 
to indirectly develop performance, pedagogical, aesthetic, cognitive, - intellectual aspects of formation of artistic and figurative thinking of students-vocalists. Thus, in the process of introducing a step-by-step method of forming artistic and figurative thinking of future singers, which contains professional-orientation, information-analytical, performance-organizational and methodological-generalizing stages, the following work was performed.

The first stage (professional orientation) is aimed at creating a positive motivational attitude of students to vocal art. This stage involves acquainting students with the laws of the process of artistic and figurative thinking in parallel with laying the foundations for understanding the essence of the methodological aspect of vocal learning. For this purpose, the methods aimed at understanding by students of figurative and art maintenance of the executed work are used. This stage lasts as part of individual voice training sessions. It provides for the purposeful involvement of vocal students in methodologically active observation of work in the vocal class. It is appropriate to note that it absorbs two elements: 1) the creation of a "situation of success" and 2) the formation of an attitude to perform vocal and professional activities. The learning process primarily involves changes in the motivation of vocal and auditory activities through positive emotions. The highest goal of the educational process is the practical readiness for productive activity through the formation of a singing standard and the so-called "regulatory image" (Emelyanov, 1999: 7). Assimilation of the algorithm of vocal-auditory diagnosis is carried out in two directions: first, in the process of vocal-auditory perception of one's own singing; secondly, in the process of vocal-auditory diagnosis of the singing process of others in classes on professional-oriented practice. This also applies to the process of formation of vocal-auditory skills, which unfolds over time and takes place in various types of educational activities, and then improves in the course of practical activities.

The formation of the motivational component combines traditional and non-traditional areas of vocal training; there is also an operational element of the process of vocal training of student vocalists, which is a necessary condition for the successful implementation of vocal-auditory diagnostics. In all such cases, tactful tutoring of the vocational practice of student vocalists is too important, for whom the stage and pedagogical style of the mentors should be a role model.

When using the methodology of problem-based learning, a special style of mental activity is formed, research activity and independence of student's increase, they learn to think logically, scientifically, creatively. In addition, the fact of subjective "discovery" of truth and the very process of its search evokes deep intellectual feelings, including a sense of satisfaction and confidence in their abilities. And emotionally colored "experienced" knowledge is more likely to take root in the mind for a long time than obtained in the finished form.

The second stage (information-analytical) is designed to form students' aspirations for continuous self-improvement. This stage of vocal-methodical training involved students' awareness of the functions of vocal learning; generalization of knowledge by systematization of educational material on the basics of vocal methodology and history of vocal performance; acquaintance of future singers with classical and new methods of development of their artistic and figurative thinking, vocal-performing skills, interpretation of corresponding musical styles; formation of a system of scientific knowledge through the mastery of the conceptual and terminological apparatus of learning.

This stage covers the lecture and seminar forms of education, which implements the content of the courses "History of Vocal Performance", "Vocal Methodology" and "Methods of teaching the profession". Along with the traditional (lectures, seminars, practical classes) there are specially developed means of vocal and methodological training, such as: modeling of problem situations that arise in the process of vocal training; application of pair-role micro-teaching; conducting open classes (master classes) with their further discussion. The information-analytical stage is carried out at the third and fourth year of professional training of the future vocalist.

The content of lecture courses provides acquaintance of students with a retrospective of views of vocal pedagogy on process of vocal training, with development of methodical thought in the historical, national and world aspect; awareness of the content of basic professional definitions; understanding the essence, structure and principles of functioning of the vocal apparatus; equipping future singers and teachers-vocalists with knowledge of the basics of formation and development of the singing voice; formation of a system of scientific knowledge by mastering the conceptual and terminological thesaurus and the formation of vocal-auditory and communicative thesaurus.

At the second stage, the work is aimed at the formation of the following indicators of artistic and figurative thinking of vocal students: the presence of knowledge and ideas in the field of vocal art; the level of formation of the professional thesaurus of students; 
understanding the specifics of the artistic and figurative language of various genres of vocal works.

The third stage (performing and organizational) involves the development of students' ability to independently compose both educational vocal programs and concerts, focused on different audiences. The following methods and techniques are used: methodical analysis of vocal material; variable-emotional interpretation of the artistic and figurative content of vocal works; involvement of students in ensemble music making; application of various forms of rehearsals (from fragmentary performance of each work to integral reproduction of the concert program); mastering the skills of vocal management and administration, etc. This stage also covers the third or fourth courses of vocal students, - when they have already accumulated a certain performing repertoire and developed skills of working on an artistic image.

The highest degree of creative activity of vocal students occurs in such an organization of the educational process that would best promote the development of skills of independent search work associated with the development of flexibility, originality, associativity, creativity of artistic and figurative thinking. The ability to reveal the artistic idea of a vocal work, to show its role in musical culture, the work of a master largely determines success. That is why it is necessary to teach vocal students to combine the use of methods of studying a musical work with exploratory activities to reveal the artistic and figurative content and subsequent inspired creative story about artistic features, history of writing, performing traditions and more. One of the ways to form the skills of artistic thinking and creative independence is to develop the ability of future vocalists (especially pop specialty) to musical improvisation, which is to create special exercises based on the work taken to study. Implementation of individual learning tasks, such as expanding musical horizons, students study music, pedagogical, methodological literature, creative development, requires the teacher to focus and be active in observing the vocal process, analytical skills, creative imagination, independence of artistic thinking. The method of parallel study of vocal works by the student (with the teacher, the accompanist and independently) promotes this all the best. The teacher-vocalist sometimes uses the so-called method of "quasi-mistakes": when the correct vocal technique, tempo, dynamics, rhythm of the work are specially changed. Stimulation by the teacher of another method - a variable approach to the performed work promotes the development of students' independence of judgment, creativity, emotional sensuality, finding their vision of the concept of the work and compli- ance of their singing with the auditory standard. It develops independence, confidence, informationally enriches the vocalist, gives new impulses for the formation of artistic and figurative thinking. This method is quite common in vocal pedagogy and is part of the arsenal of numerous means of pedagogical improvisation (along with the so-called "role-playing games"). This allows the vocalist to avoid or, as a last resort, reduce the number of ill-considered experiments in future professional activities. Discussion and discussion of the course of such "role-playing games" develop the artistic and figurative thinking of vocal students, contributing to a much clearer formulation of professional positions, the formation of reflection, empathy, removal of muscle cramps, and emotional and behavioral stereotypes. Undoubtedly, this is exactly the necessary state, which K. Stanislavsky called "creative".

Creativity is an important link between the specifics of the formation of artistic and figurative thinking of future singers and creative potential, contributing to the use of a synthetic form of creative approach to the acquisition of professional knowledge and skills.

The very introduction of synthetic means of creative education of students in the structure of music education now means identifying internal, figurative, spiritual connections of word, sound, color, space, movement, form, gesture in the process of understanding the content of all vocal disciplines by theoretical mastery of the system. aesthetic categories and concepts, and at the level of the creative process.

It is necessary to intensify the internal, figurative, spiritual parallels between vocal and other arts at the creative level involves the introduction into the educational process of vocal students subjects of theoretical and methodological, historical, performing and pedagogical cycles. It is also the performance by students-vocalists of various types of synthetic creative tasks aimed at creative combination of vocal activity with literary, theatrical, dance, etc.

Indeed, in many works analyzed by the author on music pedagogy and psychology there is a tendency to improve the musical training of vocal students through the use of a creative component, the internal mechanism of which is to increase attention to analytical methods of theoretical analysis (conceptual and categorical generalization of expressive means). semantic, structural, intonation, comparative and study of the elements of musical language in terms of their aesthetic and psychological impact.

It is obvious that in general the creative approach actualizes the formation of the future singer and teacher-vocalist in unity with the development of his artistic thinking, allows the use of universal sys- 
temic artistic influence based on pedagogically oriented interaction and synthesis of different arts. This approach in the process of forming artistic and figurative thinking combines individual, group and various forms of practical training of vocal students. We should keep in mind the peculiar system of linguistic and vocal means, which embodies the universal worldview of singers in the form of artistic images (as well as other arts, and with the help of purely linguistic means), and the so-called professional thesauri (Antonyuk, 1999: 5).

At the third stage, the work should be aimed at forming the following indicators of artistic and figurative thinking of students-vocalists, namely:

- original approach to solving problems;

- the presence of associative and figurative thinking;

- readiness for independent creativity.

Obvious mastery of professional skills and abilities of independent work, ability to self-analysis and critical self-assessment, high mobility in unforeseen situations of concert-performing and pedagogical production in the conditions of professionally-oriented practice are all manifestations of the correct methodical approach of the third stage of artistic thinking.

The fourth stage (methodological and generalizing) allows students to understand the generalized model of future professional activity: through the creation of independent methodological projections - to the actual use of appropriate methods and techniques of vocal training in pedagogical practice. It should be carried out in the conditions of pedagogical practice of students of music universities.

In this regard, it should be noted that V. Antonyuk the author of numerous scientific and methodological works, a teacher of professional disciplines at the Department of Solo Singing NMAU. P. Tchaikovsky - successfully applies new pedagogical technologies that contribute to the acquisition of comprehensive professional experience and true professional self-determination of students-vocalists. One of such technologies is tutoring of professionally-oriented practice of vocal students (pedagogical and performing), which, in her opinion, " $<\ldots>$ is the special type of interaction between teacher and student, in the process of which the student independently performs some educational activities, and his mentor ensures their implementation and understanding. The main purpose of tutoring of pedagogical and performing professional practice of vocalists is to create the most favorable conditions for students to gain and realize their own professional experience, on the basis of which it is possible to correct creative plans" (Antonyuk, 2007: 1; Antonyuk, 1999: 5).
Pedagogical interpretation of the phenomenon of artistic and figurative thinking in the context of the history of music is impossible without the involvement of scientific developments in musicology and theoretical and methodological achievements of vocal pedagogy, the foundations of which were laid by many scientists and practical experience of generations. Many publications considered by the author lack a vocal-pedagogical, practical orientation, taking into account the real historical and cultural context, overcoming narrow professional approaches to pedagogical understanding of this phenomenon. One of the reasons for this situation, in the author's opinion, is the uncertainty of scientific research on the involvement of artistic and figurative thinking of future singers in a wide creative volume, in lecture courses of theoretical and methodological and historical orientation of vocal performance and pedagogy, in particular, to systematize vocal thesaurus art (Antonyuk, 1999: 5).

Determining the place and functions of professional disciplines "Voice production", "Solo singing", "History of vocal performance", "Vocal methodology", "Methods of teaching the profession" in the educational complex of vocal students; substantiation of objective opportunities for revealing their creative potential in the course of individual and group classes and in the process of professionally-oriented practice, as well as research of their combination with other types of educational work in order to form in future singers a systematic, holistic view of the relationship various aspects of the development of artistic and figurative thinking at different stages of the process of its formation - an important stage in the work of the teacher.

Creative and pedagogical activity in the direction of realization of artistic and figurative thinking of students-vocalists in the context of professional training consists in creation of opportunities for expansion of limits of their general artistic erudition forms artisticaesthetic and professional speech thesaurus, promotes accumulation of experience of communication levels of integration, namely: spiritual and ideological, aesthetic and artistic, psychological and pedagogical, ethnocultural (Antonyuk, 1999: 5).

It is necessary to introduce interdisciplinary connections within the traditional teaching of other musical disciplines into the educational process of vocal students, and to teach narrowly specialized individual and group disciplines on a creative basis with the involvement of other arts. A creative approach to the education of artistic and figurative thinking of student vocalists involves the involvement of young people in various types of scientific knowledge of vocal creativity. 
If a non-standard way of thinking is detected in the system of general aesthetic field or studentsvocalists have original associations, analogies, connections between certain types of art, the pedagogical process in the system of music-pedagogical education acquires the most individualized color, and it provides maximum creative self-realization. The preparation of vocal students for independent work should also be considered as a holistic complex system of professional readiness - in the form of a set of different components, namely: subjects, structures, methods, stages of development and formation and existing links that combine elements systems, means of realization of the chosen purposes and form interaction of subjects of process and desirable final result: readiness for independent professional activity. Stable and definite elements of vocal training include the purpose, structure, content of structural elements of learning; to the undefined - new tools, forms, methods of preparing students for future vocal and pedagogical activities.

The concept of readiness for the formation of artistic and figurative thinking in vocal students in the process of vocal and pedagogical activities includes the following components: a) scientific and theoretical readiness as a necessary amount of vocal and theoretical knowledge; b) practical readiness as the formation at a certain level of vocal-technical, vocal-performing and vocal-auditory skills; c) psychophysical readiness as the presence of appropriate prerequisites for the success of mastering vocal and pedagogical activities.

Conclusions. The step-by-step method of forming artistic and figurative thinking of future specialists contains four stages, namely: professional-orientation, information-analytical, executive-organizational, methodical-generalizing. The first stage (professional orientation) is aimed at creating a positive motivational attitude of students to vocal art. The second stage (information-analytical) is designed to form the desire of students for continuous self-improvement.

The third stage (performing and organizational) involves the development of students' ability to independently compose both educational vocal programs and concerts, focused on different audiences. The fourth stage (methodological and generalizing) allowed students to understand the generalized model of future professional activity - through the creation of independent methodological projections - to the actual use of appropriate methods and techniques of vocal training in pedagogical practice.

The proposed method has its special advantages over the existing ones, because here the starting point is a set of natural data and the ability to teach the student to sing, and not just the methodological techniques of the teacher. Its application in the process of forming the skills of artistic and figurative thinking of vocal students provides a steady increase in their readiness for professional activity.

\section{BIBLIOGRAPHY}

1. Антонюк В. Вокальна педагогіка (сольний спів) : підручник ; НМАУ ім. П. І. Чайковського. Київ : Віпол, 2007. $176 \mathrm{c}$.

2. Антонюк В. Лінгвокультурний концепт «вокальна педагогіка». Часопис Національної музичної академї Украӥни імені П. І. Чайковського. 2009. № 1 (2). С. 94-103.

3. Антонюк В. Постановка голосу : навчальний посібник. Київ : Українська ідея, 2000. 68 с.

4. Антонюк В. Прийти на світ людиною (Мовно-інтонаційний аспект родинного виховання). Рідна школа. 1995. № 6. C. $16-17.80$ c.

5. Антонюк В. Тезаурусність вокально-педагогічного мовлення. Рідна школа. 1999. № 11. С. $49-51$.

6. Богоявленская Д. Психология творческих способностей. Москва : Академия, 2002. 320 с.

7. Емельянов В. Развитие голоса. Координация и тренинг. Санкт-Петербург : Лань, 2000. 192 с.

8. Емельянов В. Фонопедический метод формирования певческого голосообразования : методические рекомендации для учителей музыки. Новосибирск : Наука, 1991. 42 с.

9. Колодуб І. Питання теорії вокального мистецтва: посібник до курсу історії та теорії вокального мистецтва. Харків : Промінь, 1995. $120 \mathrm{c}$.

10. Олексюк О. Методика викладання гри на музичних інструментах : навчальний посібник. Київ, 2004. 135 с.

11. Олексюк О. Музична педагогіка : навчальний посібник. Київ, 2006. 188 с.

12. Олексюк О., Ткач М. Педагогіка духовного потенціалу особистості: сфера музичного мистецтва : навчальний посібник. Київ : Знання України, 2004. 264 с.

13. Падалка Г. Естетична культура майбутніх учителів та умови іï формування. Вищза $і$ середня педагогічна освіта. Київ, 1991. № 15. С. 56-62.

14. Падалка Г. Музична педагогіка. Херсон, 1995. 104 с.

\section{REFERENCES}

1. Antonyuk V. G. Vocalnaya pedagogika. Vocal pedagogy (solo singing)]: [textbook / NMAU. PI Tchaikovsky]. Kiev: Vipol, 2007. 176 p. [in Ukrainian] 
2. Antonyuk V. G. Lingvokulturnui koncept "vokalna pedagogika" [Linguo-cultural concept "vocal pedagogy"]. // Journal of NMAU. P. I. Tchaikovsky. 2009. № 1 (2), P. 94-103. [in Ukrainian]

3. Antonyuk V. G. Postanovka golosy [Statement of voice]: [textbook / KNUKiM] Kiev: Ukrainian idea, 2000. 68 p. [in Ukrainian]

4. Antonyuk V. G. Pruitu na svit lydunoy [To come into the world as a person] (Linguistic and intonational aspect of family education). Native school. 1995. № 6. - P. 16-17. - 80 p. [in Ukrainian]

5. Antonyuk V. G. Tezaurusnist vokalno-pedagogichnogo movlennya [Thesaurus of vocal and pedagogical speech]. Native school. 1999. № 11. - P. 49-51. [in Ukrainian]

6. Epiphany D. B. Psihologia tvorcheskih sposobnostey [Psychology of creative abilities]. Moscow: Academy, 2002.320 p. [in Russian]

7. Emelyanov V. V. Razvitie golosa [Development of the voice. Coordination and training]. St. Petersburg: $2000 .-192 \mathrm{c.}$ [in Russian]

8. Emelyanov V. V. Fonopedicheski metod formirovania pevcheskogo golosoobrazovaniya [Phonopedic method of formation of singing voice formation: [methodical recommendations for music teachers]. Novosibirsk: Nauka, $1991 .-42$ p. [in Russian]

9. Kolodub I. S. Putannya teorii vokalnogo mustectva [Questions of the theory of vocal art]: [manual for the course of history and theory of vocal art]. Kharkiv: Promin, 1995. - 120 p. [in Ukrainian]

10. Oleksyuk O. M. Metoduka vukladannya gru na myzuchnuh instrumentah [Methods of teaching the game on musical instruments]: [textbook]. Kiev. DAKKKiM, 2004. - 135 p. [in Ukrainian]

11. Oleksyuk O. M. Myzuchna pedagogika [Music pedagogy: [textbook]. Kiev: KNUKiM, 2006. - 188 p. [in Ukrainian]

12. Oleksyuk O. M., Tkach M. M. Pedagogika dyhovnogo potencialy osobustosti: sfera myzuchnogo mustectva [Pedagogy of the spiritual potential of the individual: the field of musical art]. Kiev: Knowledge Ukraine. 2004. - 264 p. [in Ukrainian]

13. Padalka G. M. Estetichna kyltyra maibutnih vcheteliv ta ymovu formyvannya [Aesthetic culture of future teachers and conditions of its formation]. Kiev. 1991. - P. 56-62. [in Ukrainian]

14. Padalka G. M. Myzuchna pedagogika [Music pedagogy]. Kherson: 1995. - 104 p. [in Ukrainian] 